\title{
Parasite fauna of wild Antillean manatees (Trichechus manatus manatus) of the Andean Region, Colombia
}

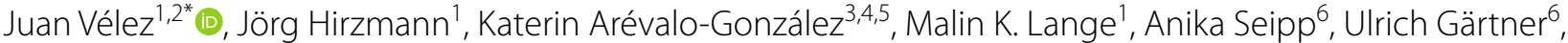 \\ Anja Taubert' ${ }^{1}$ Susana Caballero ${ }^{3}$ and Carlos Hermosilla ${ }^{1}$
}

\begin{abstract}
Background: Antillean manatees (Trichechus manatus manatus) are large herbivorous aquatic mammals living in limited areas of South, Central and North America. As with other aquatic mammals, Antillean manatees can be infected by a variety of protozoan and metazoan parasites, some of them with zoonotic potential, which affect not only their welfare but also population health status. Therefore, we conducted the first epidemiological survey in Colombian free-ranging Antillean manatees to estimate their actual gastrointestinal parasite status.

Results: In total, 69 faecal samples were collected from free-ranging individual manatees during ecology field studies in the rivers Carare and San Juan and in two associated wetlands in the Andean region of Colombia. Parasite diversity encompassed six different endoparasite species. The highest prevalence was found for protozoan infections with Eimeria nodulosa (47.8\%) and Eimeria manatus-like species (type A, B; 43.4\%), followed by Entamoeba sp. (14.49\%) and Giardia sp. (1.4\%) infections. In addition, infections with the trematode Chiorchis fabaceus were detected at a high prevalence (33.3\%). Molecular characterization of sirenian Eimeria species led to the distinction of three species, E. nodulosa and two E. manatus-like species (type A, B). Phylogenetic analyses indicated a host-specific adaptation of sirenian Eimeria species as previously reported for Eimeria species from other mammalian hosts.

Conclusions: This study provides the first record of Antillean manatee infection with Giardia and Entamoeba species in Colombia, representing two important anthropozoonotic parasite genera. This survey should serve as a baseline investigation for future monitoring on parasitic zoonoses in this mammal and encourage for investigations on their impact on both public health and wild manatee welfare.
\end{abstract}

Keywords: Manatees, Trichechus manatus manatus, Eimeria, Phylogeny, Chiorchis, Entamoeba, Giardia

\section{Background}

The Antillean manatee (Trichechus manatus manatus) is the only sirenis, which ranges from the northeast of South America through the Caribbean Sea up to Mexico. It inhabits costal, freshwater fluvial and wetland environments in Colombia [1, 2]. In contrast to other aquatic/ marine mammals, which all exhibit carnivorous/piscivorous diets, sirenians are considered as pure herbivorous species. In Colombia, Antillean manatees reside in the

\footnotetext{
*Correspondence: juan.velez@vetmed.uni-giessen.de

${ }^{1}$ Institute of Parasitology, Biomedical Research Center Seltersberg (BFS),

Justus Liebig University Giessen, Schubertstr. 81, 35392 Giessen, Germany

Full list of author information is available at the end of the article
}

Orinoco and the Caribbean basins with the Magdalena riparian system representing the largest habitat area with the highest capture [1-4]. The Antillean manatee is listed as a seriously endangered species in Colombia experiencing a threatening population decrease according to the International Union for the Conservation of the Nature (IUCN) $[1,5]$. The latest assessment referred to a population of approximately 500 animals left in these Colombian regions [6].

There are several reports highlighting the devastating impact of anthropogenic and environmental pressure on wild manatee populations due to hunting activities $[1,2]$, watercraft collisions $[5,7-11]$, sewage pollution, 
brevetoxicosis, [12-15], accidental death in fishing nets [16] and loss of natural habitats [1]. Unfortunately, the Colombian wild manatee populations are still exposed to all these adverse factors and therefore urgently require ongoing national protection measures. Besides the factors mentioned above, parasitoses also have a critical impact on wildlife population health, including that of aquatic mammals [17-20], and data on actual infections are needed to assess environmental risk factors for endangered species [21]. As such, monitoring studies will allow gaining an improved knowledge on pathogen diversity and relevance for manatee welfare, on a potential spillover of human parasites and on parasite reservoirs [20]. All these aspects are important, not only for conservation purposes, but also for the preservation of important ecological dynamics and human health protection.

So far, several reports on metazoan and protozoan parasites of manatees from different geographical regions have been published [4, 11, 22-28]. Nonetheless, detailed knowledge on manatee parasites, i.e. their biology, epidemiology, pathogenesis and immunity, is still limited and restricted to studies on captive animals or carcasses [4, 11, 29]. Consequently, these parasitological reports may not necessarily reflect true parasite diversity of manatee populations living within their natural habitats. Few investigations have been performed on South American wild manatee populations due to the elusive behaviour of these animals and the turbid waters they inhabit [21, 30, 31]. Overall, the implementation of 'non-invasive' sampling techniques (e.g. by collecting faeces, vomitus, expirations), of photographic records in combination with sonar-based manatee tracing [32] and of molecular approaches [21], may not only contribute to improve sampling efficacy but will also change the scope of future parasitological studies on manatees within natural ecosystems. Whilst there are vast amounts of molecular data available for parasites affecting terrestrial mammals, there is still a lack of molecular analyses on parasites occurring in wild manatees. Currently, sequences from only three helminth species of manatees are available $[21,33]$. The option to identify and characterize parasite diversity via DNA amplification from faeces, nasal/ ocular secretions and tissue samples opens a wide range of future tasks that may help to protect this unique mammal.

The present study represents the first large-scale survey on gastrointestinal parasites of wild, living and free-ranging Antillean manatees $(n=69)$ in Colombia and provides first report of the genus Entamoeba in sirenians in South America. Furthermore, it adds a novel molecular characterization on monoxenous Eimeria species infecting these endangered aquatic mammals.

\section{Results}

Parasite infections

Overall, 72\% (50/69) of Antillean manatees were infected with at least one parasite species (Table 1). In total, six different gastrointestinal parasite species belonging to protozoan and metazoan taxa were diagnosed. Five different protozoan and one metazoan parasitic stages (i.e. cysts, oocysts and eggs) were detected. Metazoan parasites were represented by one trematode species (Chiorchis fabaceus). No stages of cestodes, nematodes or acanthocephalans were found in manatee faecal samples. A list of known parasitic stages and respective prevalences from manatees is presented in Additional file 1: Table S1. In addition, selected illustrations of parasitic stages are given in Fig. 1.

The most prevalent parasitic stages were oocysts of Eimeria nodulosa (47.8\%; Fig. 1b), followed by Eimeria manatus-like oocysts (43.4\%; Fig. 1a), eggs of C. fabaceus (33.3\%; Fig. 1d) and cysts of Entamoeba sp. (14.5\%; Fig. 1c). One faecal sample proved positive for Giardia antigen (1.4\%) in coproantigen-ELISA. None of the identified parasites revealed as core species (prevalence $>50 \%$ ) and the diplomonadid protozoan Giardia sp. was found as component species (prevalence $<10 \%$ ). Two parasite genera have anthropozoonotic potential, namely Entamoeba and Giardia.

Referring to parasite genus level, the present findings include one new host record on Entamoeba for Antillean manatees ( $T$. manatus manatus) in South America. In addition, giardiasis has not previously been reported to occur in Colombian manatees.

Overall, two water-borne parasitic infections (i.e. giardiasis and entamoebiasis), one gastropod-borne disease (chiorchiosis) and two monoxenous infections (coccidiosis) were detected in this epidemiological survey.

Morphometric and morphological analyses of coccidian oocysts and trematode eggs revealed the following data: E. nodulosa oocysts had a mean size of $12.55 \times 11.72$ (7.0-14.9 × 7.2-13.97) $\mu \mathrm{m}$ and showed characteristic knob-like structures on the surface (Fig. 1b). Scanning electron microscopy (SEM) analyses illustrated these

Table 1 Prevalence of parasites in wild Antillean manatees (T. manatus manatus) ( $n=69)$ from the Carare River, Santander

\begin{tabular}{lll}
\hline Species & Prevalence (\%) & Technique \\
\hline Eimeria nodulosa & 47.8 & SAF/flotation \\
Eimeria sp. A and Eimeria sp. B & 43.4 & SAF/flotation \\
Entamoeba sp. & 14.5 & SAF \\
Giardia sp. & 1.4 & Copro-ELISA \\
Chiorchis fabaceus & 33.3 & SAF/sedimentation \\
\hline
\end{tabular}




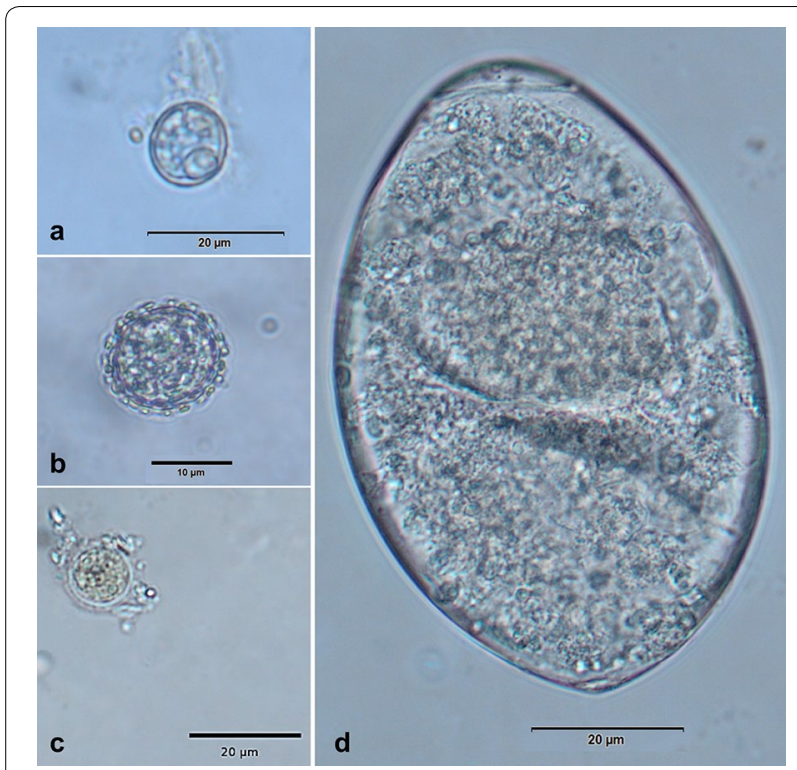

Fig. 1 Illustration of manatee gastrointestinal parasites. a Eimeria manatus-like oocyst, b Eimeria nodulosa oocyst, c Entamoeba sp. cyst, d Chiorchis fabaceus egg. Scale-bars: a, c, d 20 нm; b $10 \mu \mathrm{m}$

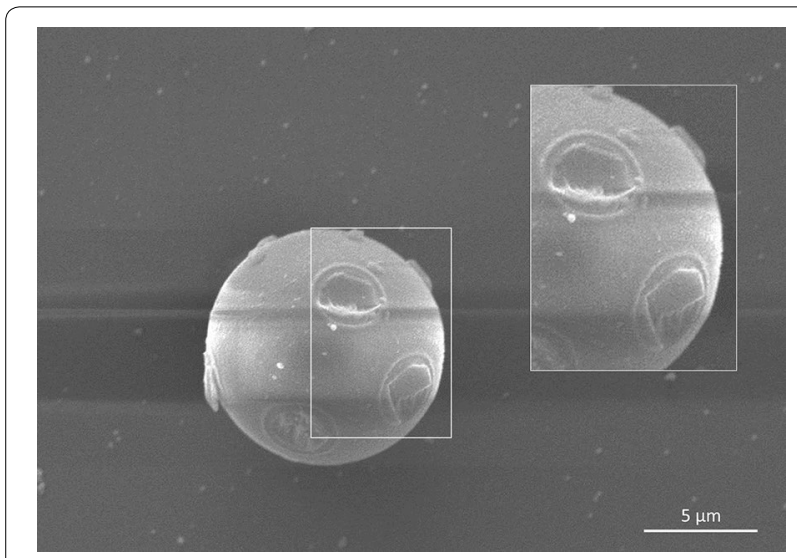

Fig. 2 Scanning electron microscopy (SEM) image of a Eimeria nodulosa oocyst. Scale-bar: $5 \mu \mathrm{m}$

knob-like structures in more detail (Fig. 2). E. manatuslike oocysts $[9.82 \times 9.24 \quad(8.9-11.95 \times 8.0-11.31) \quad \mu \mathrm{m}]$ were slightly smaller than $E$. nodulosa oocysts and lacked any knob-like structures on oocyst wall. SEM analyses showed a micropyle-like cap structure in the E. manatus-like oocysts (data not shown). Interestingly, such a structure was not reported before for manatee-specific oocysts [25, 26]. Entamoeba sp. cysts had a mean size of $14.19 \times 12.0(10.45-18.57 \times 8.17-15.89) \mu \mathrm{m}$ and presented at least more than two spherical nuclei (Fig. 1c). Chiorchis fabaceus eggs had a mean size of $151 \times 111$
(139-157 ×99-133) $\mu \mathrm{m}$, an ovoid shape, a unipolar operculum and a brownish morula being delimited by a smooth capsule (Fig. 2d). All these morphological characteristics agree with previous descriptions [25].

\section{Molecular analyses of Eimeria species}

In total, 62\% (43/69) of Antillean manatee faecal samples contained Eimeria oocysts, which were diagnosed morphologically as $E$. nodulosa and $E$. manatus-like species. A subset of samples $(n=17)$ with single and mixed Eimeria oocyst specimen was characterized molecularly by copro-PCR and consecutive sequencing of the almost entire SSU rDNA. Overall, three different Eimeria sequences were identified with an interspecies identity of $98.3-98.7 \%$ (Fig. 3, partial alignment). The highest homology obtained by BLAST search of the GenBank database was related to Eimeria sequences from rodents showing 96-97\% identity. Out of the phylogeny DNA sequences, one could directly be assigned to E. nodulosa based on microscopic diagnostics on samples showing mono-infections with $E$. nodulosa. The remaining two sequences corresponded to E. manatus-like oocysts. These appear to represent two distinct Eimeria species (designated here as E. manatus-like type A and B) which were indistinguishable on the level of oocyst morphology. The partial SSU rRNA gene sequences of E. nodulosa and the two E. manatus-like species were deposited in the GenBank database under the accession numbers MG652357-MG652359.

A simplified phylogenetic tree showing representative Eimeria species from bovines, rodents and chickens was generated based on BLAST search data including manatee Eimeria sequences (Fig. 4). Statistical analyses from series of likelihood-ratio tests obtained in MrModeltest v.2 [34] allowed to select SYM+G as the most appropriate mathematical model for our phylogenetic analysis which was carried out using MrBayes v.3.2 [35]. The Bayesian maximum posterior probability tree with corresponding clade-credibility values is shown in Fig. 4. The inferred phylogenetic tree revealed a host-specific adaptation of the sirenian Eimeria species as also shown for Eimeria species from the other host groups. The closest neighbour to the cluster of sirenian Eimeria species was represented by the rodent lineage.

\section{Discussion}

Overall, manatees were infected with five different intestinal protozoan parasites (i.e. E. nodulosa, E. manatuslike type A and B, Entamoeba sp. and Giardia sp.) and one intestinal trematode parasite, i. e. C. fabaceus. Thus, manatees were found to be infected with $E$. nodulosa (47.8\%), E. manatus-like specimens (43.4\%), Entamoeba sp. (14.5\%) and C. fabaceus (33.3\%). Giardia sp. revealed 

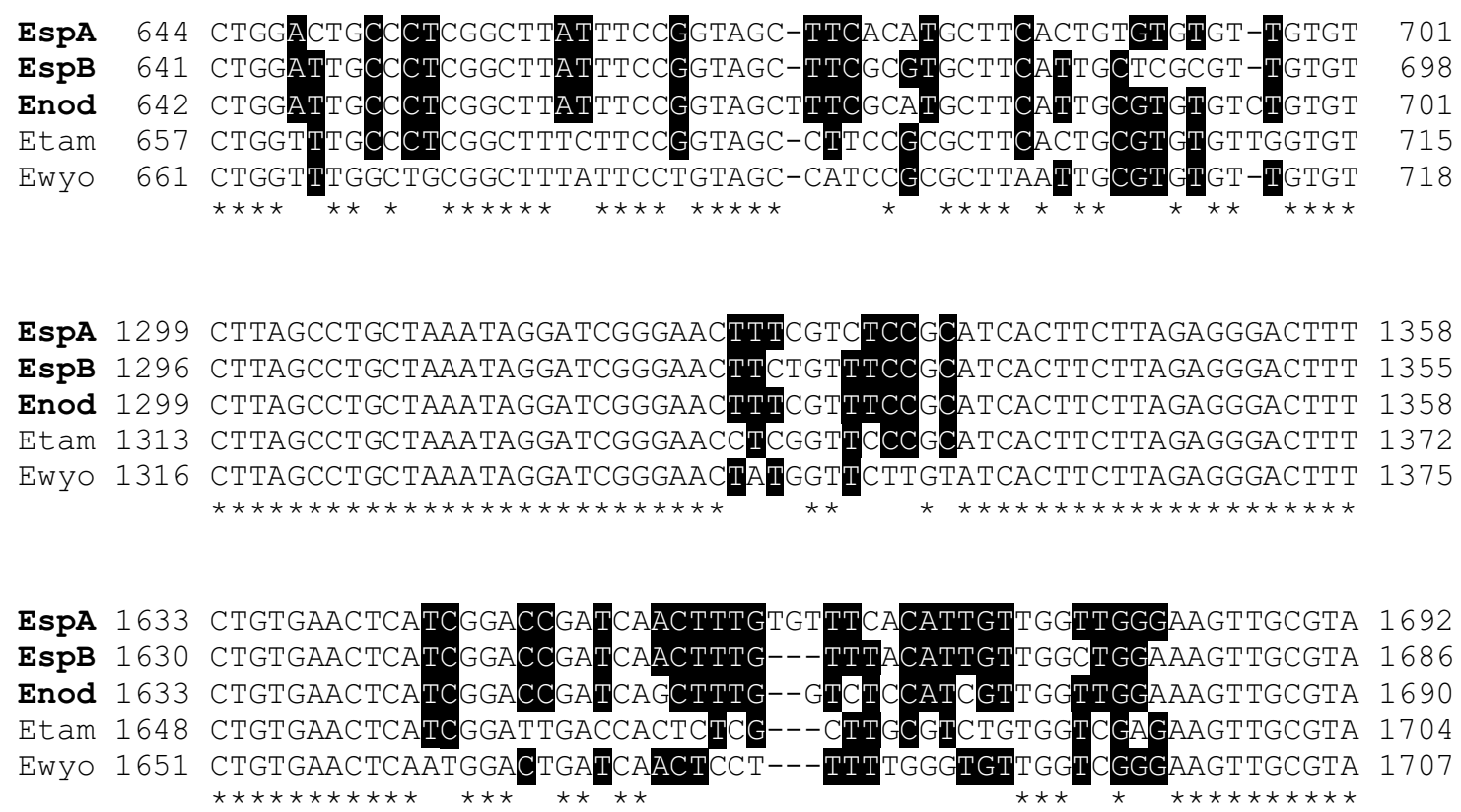

Fig. 3 Alignment of Eimeria nodulosa, Eimeria manatus-like type A, Eimeria manatus-like type B, E. tamiasciuri (squirrel) and E. wyomingensis (bovines) SSU rRNA gene sequences. Positions with identical nucleotides in all five sequences are denoted by a star; positions with more than $50 \%$ agreement are highlighted by black shading

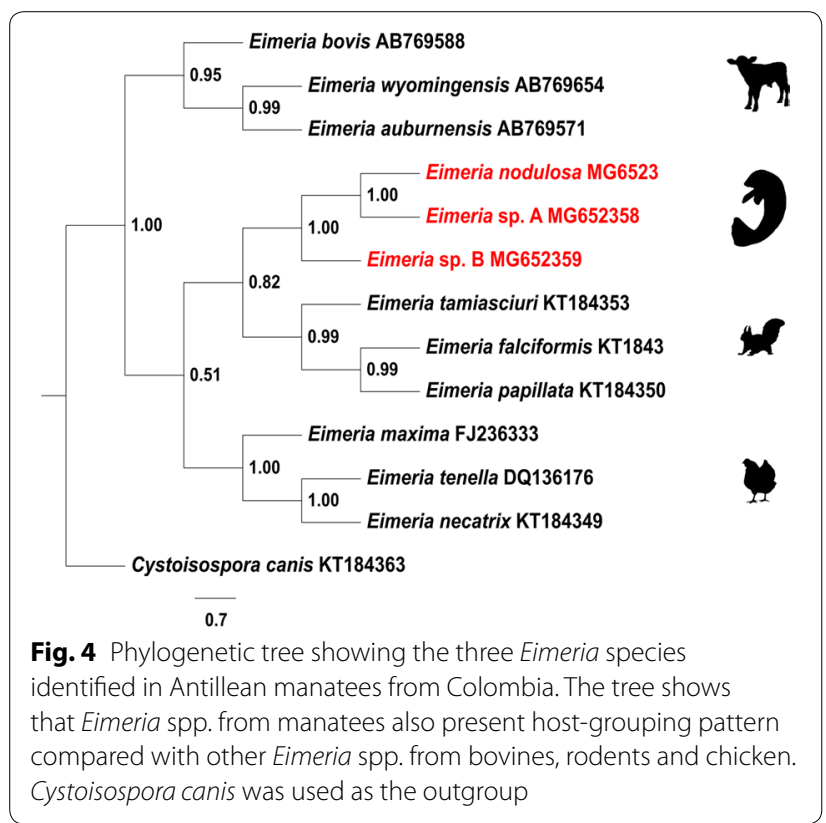

as a component species (prevalence $<10 \%$ ), which is in agreement with previous published data [31].

In the present study, Eimeria spp. revealed as the most prevalent parasites and these findings are in agreement with data on manatees inhabiting Florida and Puerto
Rico (Additional file 1: Table S1) [25, 36]. DNA sequencing-based analyses identified three Eimeria species in Colombian manatee samples, i.e. E. nodulosa and two E. manatus-like species. Although microscopic analyses revealed smaller sizes of E. manatus-like oocysts when compared to measures recently reported for E. manatus [25], the present size characteristics almost matched those described elsewhere [37]. Based on oocyst size we could also exclude the presence of $E$. trichechi, which was described in T. inunguis in Brazil [24].

Interestingly, the Antillean manatee population studied here was found to be infected with only one trematode species, i.e. C. fabaceus, thereby showing a different trematode spectrum than Antillean manatees from Córdoba, Colombia, which had Nudacotyle undicola infections [21]. This might be due to the relative geographical separation of the different manatee populations. Consistently, the Carare River is localized between the Andes Mountains of Colombia and therefore far away from shores of the Atlantic Ocean where other wild Antillean manatees reside. Trematodes have indirect life-cycles and need adequate gastropod intermediate hosts to fulfil their development. Therefore, the presence or absence of specific molluscs (snails/slugs) represents a further factor for trematode diversity in manatees. However, the current lack of knowledge on epidemiology, transmission and pathogenicity of almost all parasitoses of manatees 


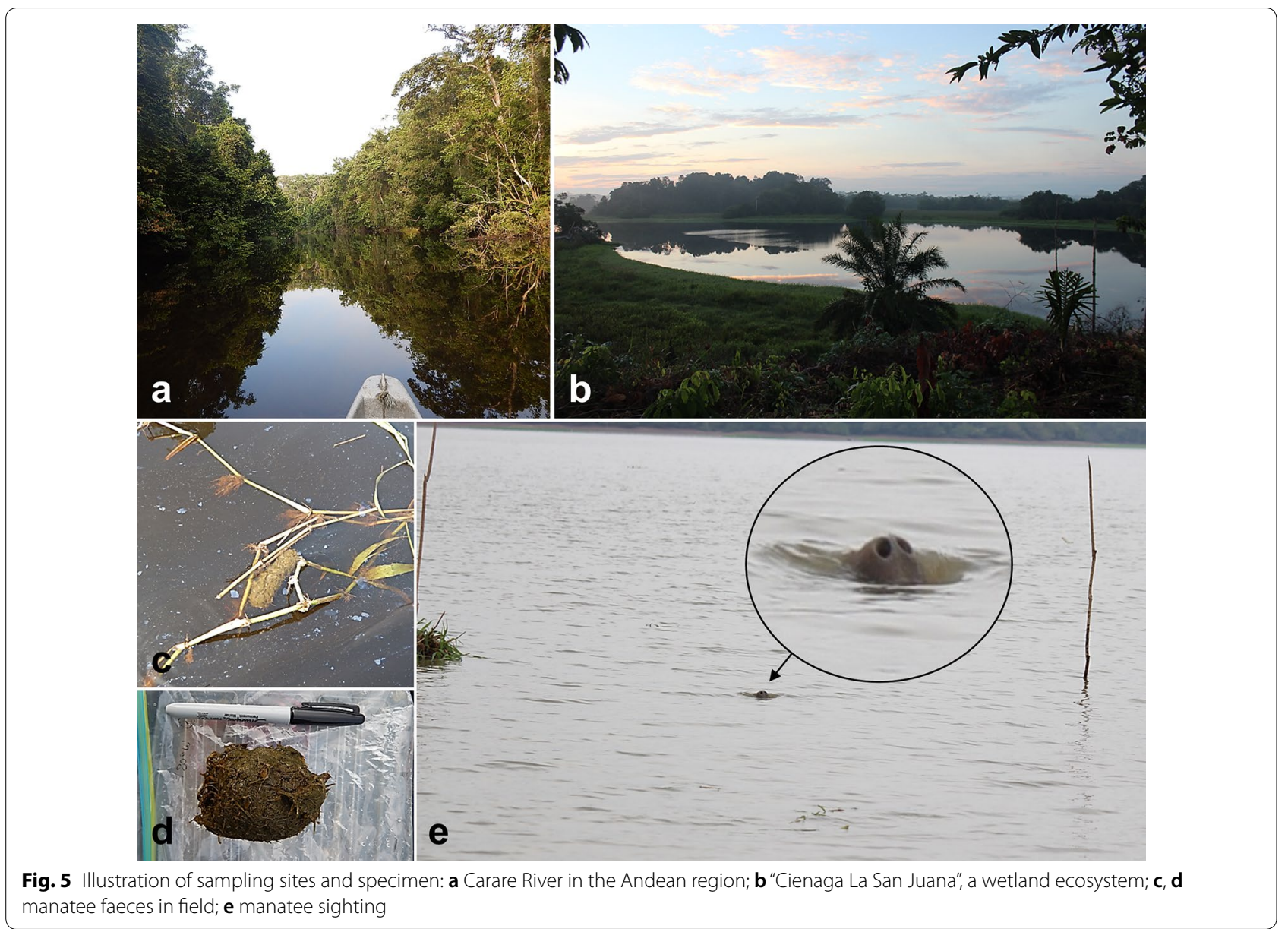

impair the establishment of proper international and national conservation politics. Indeed, the pathogenicity of manatee intestinal trematode infections, e.g. nudacotylosis, could be of importance, especially for this studied isolated manatee population which may be naïve for different manatee-specific trematode infections [25]. Additionally, the probability of a low genetic diversity in confined and remote manatee populations, a product of inbreeding, may impair the host immune system, rendering manatees more susceptible to disease as demonstrated for other wild animals [38-40].

The present parasitological findings represent the first host record for Entamoeba sp. in T. manatus manatus in South America (prevalence: 14.5\%). So far, neither the species nor the zoonotic potential of this pathogen is known. To our best knowledge, Entamoeba infections in aquatic mammals have so far only been reported in certain whale species such as sperm whales, blue whales, fin whales and sei whales [41], and there is one report for manatees [36]. Nonetheless, the Entamoeba-like cysts reported in Florida manatees [36] present a larger size and differ in the number and form of the nuclei.
Therefore, future parasitological research in manatees requires a broader approach, e.g. incorporating molecular analysis [21, 33]. In general, Entamoeba spp. are water-borne parasites and their transmission commonly occur in developing countries where drinking water quality is poor and open water often is contaminated by human faeces, which are still used as a fertilizer [42]. Besides some non-pathogenic species, such as E. coli, E. hartmanni and E. polecki [43], the genus Entamoeba also includes the worldwide occurring species $E$. histolytica which is considered as one of the major causes of human deaths induced by parasitic pathogens [44]. As such, contamination of water and shores with human faeces might pose a risk on local manatee health. Additionally, one Giardia antigen-positive Antillean manatee was identified in the present study thereby representing, to our best knowledge, the first report for Colombia. Alongside this, there is only one other report on giardiasis in manatees from Brazil [31]. Giardia spp. are also considered as water-borne zoonotic parasites which are transmitted by highly resistant cysts which are orally ingested by hosts [20]. Given that no cyst stages were detected in 
the antigen-positive animal one may question an active infection and thereby the zoonotic potential of this positive sample. In fact, we cannot exclude that Giardia stages were simply representing intestinal passers-by.

As also tackled in the present study, water-borne zoonoses clearly need more attention by public health authorities worldwide as suggested elsewhere [45]. A fundamental aspect of entamoebiasis/giardiasis control is to identify reservoirs and routes of transmission in diverse climatic and geographical areas. This is highly important in the case of wild Antillean manatees, considering that this species inhabits shallow waters close to populated marine shores which renders them highly vulnerable to classical water-borne parasitic infections $[23,30,46]$.

\section{Conclusions}

The present study adds novel data on clearly neglected anthropozoonotic parasitoses $[44,47]$ and calls for more integrated investigation to avoid exposure of Antillean manatees or human beings to these intestinal pathogens. It is of particular importance to strengthen interdisciplinary health agendas which favour 'One Health' concept considering ecosystem, domestic animal, wild animal and human health as a single unit [47-50]. This study emphasizes the relevance of the sentinel role of manatees [51] and the regular manatee monitoring programmes being supported by both Colombian authorities for public health issues and biologists/ecologists responsible for conservation programmes.

\section{Methods}

\section{Study area, sample collection and coprological analyses}

Wild Antillean manatees (T. manatus manatus) inhabiting river-, swamp- and wetland-waters within the Andean region of the Santander Department of Colombia were sampled. The study area has an average annual precipitation of $2955 \mathrm{~mm}$ and a temperature range between 26.8 and $30.3{ }^{\circ} \mathrm{C}$. Faecal samples were collected during dry and rainy seasons of the years 2015 and 2016. In detail, a boat-based line transect survey was conducted to search for faecal samples along the banks and floating plant patches in the San Juan River, the San Juana swamp and in the Carare river basin. In total, 69 individual faecal samples were collected by tracing individual animals during boat excursions according to the Guidelines for the Treatment of Marine Mammals in Field Research of the Society for Marine Mammalogy. Whenever defecation occurred, floating faecal samples were immediately collected from water surfaces or from floating vegetation patches using a net (Fig. 5). Thereafter, faecal samples were transferred into 10-ml plastic tubes (Sarstedt, Nümbrecht, Germany) containing 70\% ethanol for fixation and stored at $4{ }^{\circ} \mathrm{C}$ until further diagnosis. This survey comprised a total of 130 boat trips covering a distance of $585 \mathrm{~km}$ and resulted in $288 \mathrm{~h}$ of sampling effort.

For parasitological examination, faecal samples of manatees were submitted and analysed using Sheather's sedimentation, flotation (SSF)-technique [52] and the standard sodium acetate acetic formalin (SAF)-technique modified with ethyl acetate [53]. Whilst the SSFtechnique was applied for trematode egg diagnosis, the SAF-technique was used for detection of helminth eggs and protozoan stages (trophozoites, cysts, sporocysts, oocysts). Samples were analysed by light microscopy (BH-52 ${ }^{\circledR}$ microscope equipped with a $\mathrm{SC} 30^{\circledR}$ digital camera, both Olympus, Hamburg, Germany) and CellSens ${ }^{\circledR}$ imaging software (Olympus) for illustration (Fig. 1) and specimen measurements. Additionally, carbol-fuchsinstained faecal smears were performed for Cryptosporidium spp. oocyst detection [53, 54]. As shown for other marine mammals [41, 55-57], coproantigen-ELISAs (ProSpecT ${ }^{\mathrm{TM}}$, Thermo Scientific ${ }^{\mathrm{TM}}$, Schwerte, Germany) were applied to detect Cryptosporidium and Giardia antigens in manatee faecal samples.

\section{Molecular analyses}

Amplification of Eimeria-specific DNA via PCR and amplicon sequencing was performed to characterize Eimeria oocysts in manatee faecal samples $(n=17)$ and to elucidate phylogenetic relationships.

\section{DNA extraction of Eimeria-oocysts from faecal samples}

DNA was extracted from faecal samples using a QIAamp DNA Stool Mini kit ${ }^{\circledR}$ (Qiagen, Hilden, Germany) following glass bead homogenization [58]. First, the ethanol used for sample preservation was removed through evaporation by opening the collection tubes at room temperature for $30 \mathrm{~min}$. Then, $6 \mathrm{ml}$ of ASL buffer (Stool lysis buffer, QIAamp DNA Stool Mini kit ${ }^{\circledR}$ ) and 30 sterile glass beads ( $4 \mathrm{~mm}$ diameter, Carl Roth, Karlsruhe, Germany) were added to $1 \mathrm{~g}$ of faeces. Samples were mixed by horizontal vortexing (Vortex Genie $2^{\circledR}$, Scientific Industries Inc, New York, USA; equipped with a 13000-V1-15 adapter, MO BIO Labs, Qiagen, Hilden, Germany) and incubated at $70{ }^{\circ} \mathrm{C}$ for $15 \mathrm{~min}$. Afterwards, samples $(2 \mathrm{ml})$ were transferred to a reaction tube (Eppendorf, Berzdorf, Germany), incubated at $95{ }^{\circ} \mathrm{C}$ for $10 \mathrm{~min}$ and then pelleted (14,000 $\times$ rpm, $1 \mathrm{~min})$. Subsequently, an InhibitEX Tablet $^{\circledR}$ (Qiagen) was added to $1.2 \mathrm{ml}$ of the supernatant. DNA isolation was then performed according to the manufacturer's protocol.

\section{Eimeria-specific PCR, cloning and sequencing}

Eimeria-specific primers were used in a nested PCR, namely, TK2: 5'-GGT TGA TCC TGC CAG TAG TC- $3^{\prime}$ and ETS2: 5'-AAT CCC AAT GAA CGC GAC 
TCA-3' for PCR1 and TK1: 5'-AGT AGT CAT ATG CTT GTC TC-3' together with 18S-14R: 5'-ACG GAA ACC GTG TTA CGA CT-3' for PCR2, according to [59]. The nested PCR produced a fragment ( 1800 bp) of the small subunit ribosomal DNA (SSU rDNA). For PCR1, the reaction volume of $50 \mu \mathrm{l}$ contained $0.2 \mu \mathrm{M}$ of each primer (TK2, ETS2), $10 \mu \mathrm{l}$ of $5 \times$ HOT FIREPol Blend Master Mix with $7.5 \mathrm{mM} \mathrm{MgCl}$ (Solis BioDyne, Tartu, Estonia) and $5 \mu \mathrm{l}$ of copro-DNA template. The cycling programme was: $95^{\circ} \mathrm{C}$ for $15 \mathrm{~min}$ (initial denaturation) followed by 30 cycles of $95{ }^{\circ} \mathrm{C}(20 \mathrm{~s}$, denaturation), $67^{\circ} \mathrm{C}$ decreasing $1{ }^{\circ} \mathrm{C}$ per cycle until $60{ }^{\circ} \mathrm{C}(30 \mathrm{~s}$, annealing) and finally $72{ }^{\circ} \mathrm{C}$ for 2 min $30 \mathrm{~s}$. For PCR2, $2 \mu \mathrm{l}$ of amplificate (PCR1) was used as a template using the following conditions: $95^{\circ} \mathrm{C}$ for $15 \mathrm{~min}$ (initial denaturation), followed by 35 cycles of $95^{\circ} \mathrm{C}, 20 \mathrm{~s}$ (denaturation), $56{ }^{\circ} \mathrm{C}$ for $30 \mathrm{~s}$ (annealing) and $72{ }^{\circ} \mathrm{C}$ for $2 \mathrm{~min}$. PCR-derived DNA samples were analysed in a $1 \%$ agarose gel. Subsequently, DNA-amplicons were purified from a preparative agarose gel (1\%) using HiYield ${ }^{\circledR} \mathrm{Gel} /$ PCR DNA Extraction Kit (Süd-Laborbedarf, Gauting, Germany). Afterwards, the amplicons were cloned into pDrive vector (Qiagen) and the isolated recombinant plasmid DNA with amplicons was sequenced in both directions by LGC Genomics (Berlin, Germany).

\section{Phylogenetic analysis on manatee Eimeria spp.}

The SSU rDNA sequence-based phylogenetic analysis was conducted using a reduced dataset. Nine Eimeria sequences (Fig. 4) from three different host groups (bovines, rodents and chickens) were selected after BLAST search in GenBank. Cystoisospora canis was chosen as the outgroup-member to prove the monophyly of the ingroup-members. Sequences were aligned using ClustalX v.2.1 software [60] and the alignment was corrected manually. For phylogenetic analyses, the best-fit models of sequence evolution were determined with JModelTest v.2.1.10 [61, 62] and MrModeltest v.2 [34] software applying Akaike's criterion. For maximum likelihood (ML) and Bayesian inference (BI) analyses, the following methods were used: ML analysis was performed using PhyML v.3.0 software [62] using the TIM3 + I+G model. BI analysis was conducted using MrBayes v.3.2 software [35] applying a SYM+G model for 20,000 generations. Burn-in was determined according to the indications implemented in the MrBayes software [deviation of split frequencies below 0.01 , a potential scale reduction factor (PSRF) close to 1.0 for all parameters]. The phylogenetic trees were visualized in FigTree v.1.4.3 software [63] and adjusted using Adobe Illustrator CS5 v.15.0 (Adobe Systems Inc., San Jose, USA).

\section{Scanning electron microscopy (SEM) of sirenian Eimeria oocysts}

Droplets of Eimeria spp. oocyst-positive faecal samples were deposited on circular, poly-L-lysine (Merck, Darmstadt, Germany) pre-coated glass coverslips $(10 \mathrm{~mm}$ diameter; Nunc). Thereafter, samples were fixed in $2.5 \%$ glutaraldehyde (Merck), post-fixed in 1\% osmium tetroxide (Merck), washed in distilled water, dehydrated, dried by $\mathrm{CO}_{2}$ treatment and afterwards sputtered with gold particles as described for faecal probes of other marine mammals [64]. SEM samples were analysed using an $\mathrm{XL} 30^{\circledR}$ scanning electron microscope (Philips, Hillsboro, USA) at the Institute of Anatomy and Cell Biology, Justus Liebig University Giessen, Germany.

\section{Additional file}

Additional file 1: Table S1. Prevalence of gastrointestinal and respiratory parasites in wild manatees; present study and literature review.

\section{Abbreviations}

(SAF)-technique: sodium acetate acetic acid formalin; ELISA: enzyme-linked immunosorbent assay; SSU rDNA: small-subunit ribosomal RNA gene; IUCN: International Union for the Conservation of the Nature; PCR: polymerase chain reaction; DNA: deoxyribonucleic acid; rDNA: ribosomal deoxyribonucleic acid; rRNA: ribosomal ribonucleic acid; SEM: scanning electron microscopy; WCS: Wildlife Conservation Society; CAS: Corporación Autónoma Regional de Santander.

\section{Acknowledgements}

We are thankful to "Grupo de Guardianes del Manatí de Carare y Riberas del San Juan", WCS Colombia, Ecopetrol, "Fundación Julio Mario Santo Domingo" and "Cabildo Verde Sabana de Torres", which organized the project "Wildlife" and have supported the sample collection of the study. We also extend our thanks to Dr Iván Conejeros (Institute of Parasitology, Justus Liebig University Giessen) for his contributions provided in the phylogenetic analysis.

\section{Funding}

The sample collection in this research was supported by "Grupo de Guardianes del Manatí de Carare y Riberas del San Juan", through the "Proyecto Vida Silvestre", funded by Ecopetrol, Wildlife Conservation Society, "Fundación Mario Santo Domingo" and "Cabildo Verde Sabana de Torres". The processing of samples, analysis of results and the publication of the present study did not receive any specific grant from funding agencies in the public, commercial, or not-for-profit sectors.

\section{Availability of data and materials}

All relevant data supporting the conclusions of this study are included within the article.

\section{Authors' contributions}

Conceived and designed the study: $\mathrm{CH}$ and SC. Performed the sample collection: KAG. Processed and analysed the samples: JV, JH and MKL. Produced the SEM images: AS and UG. Supervised laboratory work: $\mathrm{CH}$ and AT. Wrote the paper: JV, CH, MKL, JH, KA-G and AT. All authors read and approved the final manuscript.

\section{Ethics approval and consent to participate}

This study was conducted according to the Guidelines for the Treatment of Marine Mammals in Field Research of the Society for Marine Mammalogy. The fieldwork was conducted within the "Wild life" project by "Grupo de 
Guardianes del Manatí de Carare y Riberas del San Juan"funded by Ecopetrol, Wildlife Conservation Society, "Fundación Mario Santo Domingo" and "Cabildo Verde Sabana de Torres" and Wild life Conservation Society (WCS). The "Wildlife" Project was conducted with the permission of the "Corporación Autónoma Regional de Santander - CAS" to access the samples.

\section{Consent for publication}

Not applicable.

\section{Competing interests}

The authors declare that they have no competing interests.

\section{Publisher's Note}

Springer Nature remains neutral with regard to jurisdictional claims in published maps and institutional affiliations.

\section{Author details}

${ }^{1}$ Institute of Parasitology, Biomedical Research Center Seltersberg (BFS), Justus Liebig University Giessen, Schubertstr. 81, 35392 Giessen, Germany. ${ }^{2}$ CIBAV Research Group, Veterinary Medicine School, University of Antioquia, Calle 70 No. 52-21, Medellín, Colombia. ${ }^{3}$ LEMVA, Laboratory of Molecular Ecology of Aquatic Vertebrates, University of Los Andes, Carrera 1 No. 18A-12, Bogotá, Colombia. ${ }^{4}$ Universidad Veracruzana, km. 7,5 Carretera Túxpan-Tampico, Túxpan, México. ${ }^{5}$ Cabildo Verde Sabana de Torres, Carrera 11 No 14-75, Sabana de Torres, Colombia. ${ }^{6}$ Institute of Anatomy and Cell Biology, Justus Liebig University Giessen, Aulweg 123, 35392 Giessen, Germany.

Received: 20 January 2019 Accepted: 17 April 2019 Published online: 27 April 2019

\section{References}

1. Trujillo F, Gartner A, Caicedo D. Diagnóstico del estado de conocimiento y conservación de los mamíferos acuáticos en Colombia. Bogota: Ministerio de Ambiente y Desarrollo Sostenible FO, Conservación Internacional y WWF; 2013.

2. Montoya-Ospina RA, Caicedo-Herrera D, Millán-Sánchez SL, MignucciGiannoni AA, Lefebvre LW. Status and distribution of the West Indian manatee, Trichechus manatus manatus, in Colombia. Biol Conserv. 2001;102:117-29.

3. Bertram G, Bertram CR. The modern Sirenia: their distribution and status. Biol J Linn Soc. 1973;5:297-338.

4. Beck C, Forrester DJ. Helminths of the Florida manatee, Trichechus manatus latirostris, with a discussion and summary of the parasites of sirenians. J Parasitol. 1988;74:628-37.

5. Deutsch C, Self-Sullivan C, Mignucci-Giannoni A. Trichechus manatus. The IUCN Red List of Threatened Species. Version 2014.2. 2008. http://dx. doi. org/10.2305/IUCN.UK.2008.RLTS.T22103A9356917.en. Accessed 3 Nov 2018

6. Quintana-Rizzo E, Reynolds J. Regional management plan for the West Indian manatee (Trichechus manatus). Gosier, Guadeloupe, France: Caribbean Environment Programme, United Nations Environment Programme; 2008

7. O'Shea TJ, Beck CA, Bonde RK, Kochman HI, Odell DK. An analysis of manatee mortality patterns in Florida, 1976-1981. J Wildlife Manag. 1985:49:1-11.

8. Dierauf $\mathrm{L}$, Gulland FM. CRC handbook of marine mammal medicine: health, disease, and rehabilitation. Boca Raton: CRC Press; 2001.

9. Gomes Borges JC, Câmara Alves L, Gloria Faustino MAD. Criptosporidiose: uma revisão sobre a sua implicação na conservação dos mamíferos aquáticos. Biota Neotrop. 2007;7:3.

10. Bossart GD. The Florida manatee: on the verge of extinction? J Am Vet Med Assoc. 1999:214:1178-83.

11. Mignucci-Giannoni AA, Williams EH, Toyos-González GM, Pérez-Padilla J, Rodriguez-López MA, Vega-Guerra MB, et al. Helminths from a stranded manatee in the Dominican Republic. Vet Parasitol. 1999;81:69-71.

12. Bossart GD, Baden DG, Ewing RY, Roberts B, Wright SD. Brevetoxicosis in manatees (Trichechus manatus latirostris) from the 1996 epizootic: gross, histologic, and immunohistochemical features. Toxicol Pathol. 1998;26:276-82.

13. O'Shea TJ, Rathbun GB, Bonde RK, Buergelt CD, Odell DK. An epizootic of Florida manatees associated with a dinoflagellate bloom. Mar Mammal Sci. 1991;7:165-79.

14. Flewelling LJ, Naar JP, Abbott JP, Baden DG, Barros NB, Bossart GD, et al. Brevetoxicosis: red tides and marine mammal mortalities. Nature. 2005;435:755-6.

15. Landsberg J, Flewelling L, Naar J. Karenia brevis red tides, brevetoxins in the food web, and impacts on natural resources: decadal advancements. Harmful Algae. 2009;8:598-607.

16. Castelblanco-Martínez DN, Bermúdez-Romero AL, Gómez-Camelo IV, Rosas FCW, Trujillo F, Zerda-Ordoñez E. Seasonality of habitat use, mortality and reproduction of the vulnerable Antillean manatee Trichechus manatus manatus in the Orinoco River, Colombia: implications for conservation. Oryx. 2009;43:235-42.

17. Hudson PJ, Dobson AP, Newborn D. Do parasites make prey vulnerable to predation? Red grouse and parasites. J Anim Ecol. 1992;61:681-92.

18. Daszak $P$, Cunningham AA, Hyatt AD. Emerging infectious diseases of wildlife-threats to biodiversity and human health. Science. 2000;287:443.

19. Møller AP, Nielsen JT. Malaria and risk of predation: a comparative study of birds. Ecology. 2007;88:871-81.

20. Thompson R, Lymbery A, Smith A. Parasites, emerging disease and wild life conservation. Int J Parasitol. 2010:40:1163-70.

21. Vélez J, Hirzmann J, Lange M, Chaparro-Gutiérrez J, Taubert A, Hermosilla C. Occurrence of endoparasites in wild Antillean manatees (Trichechus manatus manatus) in Colombia. Int J Parasitol Parasites Wildl. 2018:7:54-7.

22. Bonde RK, O'shea T, Beck C. Manual of procedures for the salvage and necropsy of carcasses of the West Indian manatee (Trichechus manatus). Springfield, Virginia, USA: National Technical Information Service; 1983.

23. Bossart GD, Mignucci-Giannoni AA, Rivera-Guzman AL, Jimenez-Marrero NM, Camus AC, Bonde RK, et al. Disseminated toxoplasmosis in Antillean manatees Trichechus manatus manatus from Puerto Rico. Dis Aquat Organ. 2012;101:139-44.

24. Lainson R, Naiff R, Best R, Shaw J. Eimeria trichechi n. sp. from the Amazonian manatee, Trichechus inunguis (Mammalia: Sirenia). Syst Parasitol. 1983:5:287-9.

25. Bando M, Larkin IV, Wright SD, Greiner EC. Diagnostic stages of the parasites of the Florida manatee, Trichechus manatus latirostris. J Parasitol. 2014:100:133-8.

26. Upton SJ, Odell DK, Bossart GD, Walsh MT. Description of the oocysts of two new species of Eimeria (Apicomplexa: Eimerüdae) from the Florida manatee, Trichechus manatus (Sirenia: Trichechidae). J Protozool. 1989:36:87-90.

27. Carvalho V, Meirelles A, Motta M, Maia D, Campello M, Bevilaqua C. Occurrence of Pulmonicola cochleotrema (syn. Cochleotrema cochleotrema) (Digenea: Opisthotrematidae) in Antillean manatees (Trichechus manatus manatus) in Brazil. Lat Am J Aquat Mamm. 2009;7:47-52.

28. Hernández-Olascoaga A, Olivera-Gómez LD, Morales-Vela B. Helmintos parásitos en heces de manatí Antillano Trichechus manatus manatus (Sirenia: Tricheachidae) en México: Golfo de México y Caribe. Hidrobiológica. 2017:27:39-44

29. Colón-Llavina MM, Mignucci-Giannoni AA, Mattiucci S, Paoletti M, Nascetti G, Williams EH. Additional records of metazoan parasites from Caribbean marine mammals, including genetically identified anisakid nematodes. Parasitol Res. 2009;105:1239.

30. Borges JCG, Alves LC, da Gloria Faustino MA, Marmontel M. Occurrence of Cryptosporidium spp. in Antillean manatees (Trichechus manatus) and Amazonian manatees (Trichechus inunguis) from Brazil. J Zoo Wildl Med. 2011:42:593-6.

31. Borges JCG, dos Santos Lima D, da Silva EM, de Oliveira Moreira AL, Marmontel M, Carvalho VL, et al. Cryptosporidium spp. and Giardia sp. in aquatic mammals in northern and northeastern Brazil. Dis Aquat Organ. 2017;126:25-31.

32. Buaka Muanke P, Niezrecki C. Locating manatee position with an acoustic array. J Acoust Soc Am. 2006;119:3405.

33. Nadler SA, Hudspeth DS. Ribosomal DNA and phylogeny of the Ascaridoidea (Nemata: Secernentea): implications for morphological evolution and classification. Mol Phylogenet Evol. 1998;10:221-36. 
34. Nylander JAA. MrModeltest 2.3. Program distributed by the author. Evolutionary Biology Centre, Uppsala University. 2004. http://www.abc. se/ nylander/. Accessed 2 Mar 2018

35. Ronquist F, Huelsenbeck J, Teslenko M. Draft MrBayes version 3.2 manual: tutorials and model summaries. 2011. http://evolution.genetics.washi ngton.edu/phylip/software.old.html Accessed 22 Feb 2018.

36. Wyrosdick H, Chapman A, Mignucci-Giannoni AA, Rivera-Pérez $\mathrm{Cl}$, Bonde RK. Internal parasites of the two subspecies of the West Indian manatee Trichechus manatus. Dis Aquat Organ. 2018;130:145-52.

37. Wyrosdick HL. Epidemiology of Toxoplasma gondii and a survey of other parasites in the West Indian manatee (Trichechus manatus). 2016. https:// trace.tennessee.edu/utk_gradthes/4274/. Accessed 12 Jan 2018.

38. Hale K, Briskie J. Decreased immunocompetence in a severely bottlenecked population of an endemic New Zealand bird. Anim Conser. 2007;10:2-10.

39. Pedersen $A B$, Jones $K E$, Nunn $C L$, Altizer S. Infectious diseases and extinction risk in wild mammals. Conser Biol. 2007;21:1269-79.

40. Peeler EJ, Oidtmann BC, Midtlyng PJ, Miossec L, Gozlan RE. Non-native aquatic animals introductions have driven disease emergence in Europe. Biol Invasions. 2011;13:1291-303.

41. Hermosilla C, Silva LM, Kleinertz S, Prieto R, Silva MA, Taubert A. Endoparasite survey of free-swimming baleen whales (Balaenoptera musculus, B. physalus, B. borealis) and sperm whales (Physeter macrocephalus) using non/minimally invasive methods. Parasitol Res. 2016;115:889-96.

42. Marshall MM, Naumovitz D, Ortega Y, Sterling CR. Waterborne protozoan pathogens. Clin Microbiol Rev. 1997;10:67-85.

43. Matsubayashi M, Kanamori K, Sadahiro M, Tokoro M, Abe N, Haritani $M$, et al. First molecular identification of Entamoeba polecki in a piglet in Japan and implications for aggravation of ileitis by coinfection with Lawsonia intracellularis. Parasitol Res. 2015;114:3069-73.

44. Salles JM, Salles MJ, Moraes LA, Silva MC. Invasive amebiasis: an update on diagnosis and management. Expert Rev Anti Infect Ther. 2007:5:893-901.

45. Ponce-Gordo F. Jirků-Pomajbíková, K. Balantidium coli. Global water pathogen project part three. specific excreted pathogens: environmental and epidemiology aspects. 2017. https://www.researchgate.net/publi cation/325701431_Balantidium_coli. Accessed 16 Aug 2018.

46. Jones J, Dubey J. Waterborne toxoplasmosis - recent developments. Exp Parasitol. 2010;124:10-25.

47. Thompson RA. Parasite zoonoses and wildlife: one health, spillover and human activity. Int J Parasitol. 2013;43:1079-88.

48. Schwabe CW. Cattle, priests, and progress in medicine. Minneapolis, Minnesota, USA: University of Minnesota Press; 1978.

49. Cook R, Karesh W, Osofsky S. The Manhattan principles on 'One World One Health'. One World, One Health: building interdisciplinary bridges to health in a globalized world. New York: Wildlife Conservation Society; 2004.

50. Schurer J, Mosites E, Li C, Meschke S, Rabinowitz P. Community-based surveillance of zoonotic parasites in a 'One Health' world: a systematic review. One Health. 2016;2:166-74.

51. Bossart GD. Marine mammals as sentinel species for oceans and human health. Oceanography. 2006;19:134-7.

52. Yang J, Scholten T. A fixative for intestinal parasites permitting the use of concentration and permanent staining procedures. Am J Clin Pathol. 1977:67:300-4

53. Untersuchungsmethoden Bauer C. In: Schnieder T, editor. Veterinärmedizinische parasitologie. 3rd ed. Stuttgart: Parey; 2006. p. 84-104.

54. Heine J. Eine einfache Nachweismethode für Kryptosporidien im Kot. ZBL Vet Med B. 1982;29:324-7.

55. Kleinertz S, Hermosilla C, Ziltener A, Kreicker S, Hirzmann J, Abdel-Ghaffar $F$, et al. Gastrointestinal parasites of free-living Indo-Pacific bottlenose dolphins (Tursiops aduncus) in the Northern Red Sea, Egypt. Parasitol Res. 2014:113:1405-15.

56. de Vos A, Faux CE, Marthick J, Dickinson J, Jarman SN. New determination of prey and parasite species for northern Indian Ocean Blue Whales. Front Mar Sci. 2018;5:104

57. Hermosilla C, Silva LM, Navarro M, Taubert A. Anthropozoonotic endoparasites in free-ranging "urban" South American sea lions (Otaria flavescens). J Vet Med. 2016;2016:1-7.

58. Nunes CM, Lima LGF, Manoel CS, Pereira RN, Nakano MM, Garcia JF. Fecal specimens preparation methods for PCR diagnosis of human taeniosis. Rev Inst Med Trop São Paulo. 2006:48:45-7.

59. Kokuzawa T, Ichikawa-Seki M, Itagaki T. Determination of phylogenetic relationships among Eimeria species, which parasitize cattle, on the basis of nuclear 18S rDNA sequence. J Vet Med Sci. 2013;75:1427-31.

60. Larkin M, Blackshields G, Brown N, Chenna R, McGettigan P, McWilliam H. Clustal W and Clustal X version 2.0. Bioinformatics. 2007;23:2947-8.

61. Darriba D, Taboada GL, Doallo R, Posada D. jModelTest 2: more models, new heuristics and parallel computing. Nat Methods. 2012;9:772.

62. Guindon S, Gascuel O. A simple, fast, and accurate algorithm to estimate large phylogenies by maximum likelihood. Syst Biol. 2003;52:696-704

63. Andrew Rambaut. Molecular evolution, phylogenetics and epidemiology. Andrew Rambaut's research group: FigTree. 2007. http://tree.bio.ed.ac.uk/ software/figtree/. Accessed 18 Feb 2019

64. Hermosilla C, Hirzmann J, Silva L, Brotons J, Cerdà M, Prenger-Berninghoff $E$, et al. Occurrence of anthropozoonotic parasitic infections and faecal microbes in free-ranging sperm whales (Physeter macrocephalus) from the Mediterranean Sea. Parasitol Res. 2018;117:2531-41.
Ready to submit your research? Choose BMC and benefit from:

- fast, convenient online submission

- thorough peer review by experienced researchers in your field

- rapid publication on acceptance

- support for research data, including large and complex data types

- gold Open Access which fosters wider collaboration and increased citations

- maximum visibility for your research: over $100 \mathrm{M}$ website views per year

At $\mathrm{BMC}$, research is always in progress.

Learn more biomedcentral.com/submissions 